\title{
PENERAPAN METODE WATERFALL DALAM PENGEMBANGAN SISTEM INFORMASI E-LEARNING (Studi Kasus: SMP NEGERI 5 JAYAPURA)
}

${ }^{1}$ Salahudin Robo, ${ }^{2}$ Andrian Sah, ${ }^{3}$ Andri Tri Sidarmawan, ${ }^{4}$ Muhammad Taher Jufri

${ }^{1,2,3}$ Program Studi Sistem Informasi, Fakultas Teknik dan Sistem Informasi, Universitas Yapis Papua Jl. DR. Sam Ratulangi No 11 Dok V Atas, Tlp (0967) 534012, 550355, Jayapura-Papua Isalahudinrobo759@gmail.com; ${ }^{2}$ cyberdefance23@gmail.com; ${ }^{3}$ andriblackid22@gmail.com; ${ }^{4}$ jufri.conoras@gmail.com;

\section{Article Info}

Article history:

Received, 18-05-2021

Revised, 01-06-2021

Accepted, 14-06-2021

\section{Kata Kunci:}

E-Learning

materi

pembelajaran

Keywords:

E- Learning

material

Learning

\begin{abstract}
ABSTRAK
Sekolah Menengah Pertama (SMP) Negeri 5 merupakan salah satu sekolah yang berada di tengah-tengah kota Jayapura memiliki Akreditas "A". Dalam proses pembelajaran antara guru dan siswa sangat terbatas. Siswa juga tidak mendapatkan materi pelajaran dan tugas apabila guru tidak dapat hadir, ini menyebabkan penyampaian materi pelajaran menjadi terhambat. Siswa hanya mendapatkan materi pelajaran dari guru ataupun referensi buku di perpustakaan sekolah, sehingga dapat terjadi keterbatasan tempat dan waktu untuk mengaksesnya. Hal ini yang melatarbelakangi penulis untuk membuat suatu aplikasi e-learning untuk SMP Negeri 5 Jayapura. E- learning adalah konsep pembelajaran yang dilakukan melalui jaringan media elektronik. Tujuan dari penelitian ini adalah membuat suatu aplikasi pembelajaran online sehingga membantu siswa dalam mendapatkan materi pelajaran dan pengerjaan tugas. Penelitian ini menggunakan metode pengembangan waterfall. Dengan adanya sistem ini tidak hanya dapat membantu siswa akan tetapi juga dapat membantu guru dalam memberikan materi dan tugas serta meningkatkan efisiensi dan efektivitas sistem mengajar di SMP Negeri 5 Jayapura dalam meningkatkan pembelajaran siswa.
\end{abstract}

\section{ABSTRACT}

The State 5 Junior High School (SMP) is one of the schools located in the middle of the city of Jayapura which has an "A" Accreditation. In the learning process between teachers and students is very limited. Students also do not get subject matter and assignments if the teacher cannot attend, this causes the delivery of subject matter to be hampered. Students only get subject matter from the teacher or reference books in the school library, so there can be limited space and time to access them. This is the background of the author to create an e-learning application for SMP Negeri 5 Jayapura. E-learning is a learning concept that is carried out through electronic network media. The purpose of this research is to create an online learning application so as to assist students in getting subject matter and doing assignments. This research uses the waterfall development method. With this system, it can not only help students but can also assist teachers in providing materials and assignments as well as improve the efficiency and effectiveness of the teaching system at SMP Negeri 5 Jayapura in improving student learning.

\section{Penulis Korespondensi:}

Andri Tri Sidarmawan,

Program Studi Sistem Informasi,

Universitas Yapis Papua,

Email: andriblackid22@gmail.com 


\section{PENDAHULUAN}

Standar kompetensi dunia ini semakin meningkat, hal tersebut berdampak langsung terhadap peningkatan sumber daya manusia [1]. Peningkatan SDM merupakan tuntutan yang harus dipenuhi oleh instansi pendidikan. Berbagai macam cara dan metode-metode pembelajaran yang telah di upayakan, agar siswa dapat menerima materi - materi dengan baik. Seiring dengan perkembangan teknologi informasi khususnya internet dalam sistem informasi, proses belajar mengajar telah memanfaatkan teknologi informasi tersebut baik dari jenjang pendidikan dasar, menengah maupun pendidikan tinggi [2]. Sudah saatnya dunia pendidikan Indonesia memanfaatkan teknologi informasi ini. Teknologi komunikasi dan informasi menjanjikan efisiensi, kecepatan dalam menghimpun, mengolah, mendistribusikan data, penyampaian informasi [3]. Hal ini berkait dengan meningkatnya kebutuhan informasi ilmu pengetahuan dan teknologi yang tidak banyak diperoleh dalam area sekolah. Untuk saat melakukan pertukaran informasi dan data antar sekolah, Sekolah untuk pemerintah daerah, sekolah dengan masyarakat, dan lain-lain, semuanya pasti akan lebih efektif ketika menggunakan teknologi informasi.

E- learning merupakan konsep pembelajaran yang menggunakan jaringan media elektronik. Teknologi yang sangat berkembang di era sekarang dan globalisasi memungkinkan berbagai macam kegiatan yang dilakukan secara cepat dan efisien [4] [5] [6] [7]. Perkembangan teknologi yang banyak memberikan pengaruh terhadap kehidupan kita yang sekarang, salah satunya adalah dalam bidang Pendidikan dapat menggunakan $e$ - learning dalam kegiatan ajar mengajar di sekolah, perguruan tinggi hingga tempat - tempat kursus dan komunitas - komunitas online yang sudah bisa menggunakan konsep ini [8] [9]. Dewasa ini metode belajar pengajar dari tingkat dasar sampai dengan perguruan tinggi sedikit mengalami kebosanan jika hanya menggunakan metode klasikal yakni dengan ceramah dan tanya jawab saja. Perlu adanya metode baru untuk meningkatkan semangat belajar mengajar, baik untuk siswa/mahasiswa maupun guru/dosen [10] [11].

Sekolah Menengah Pertama (SMP) Negeri 5 merupakan salah satu sekolah yang berada di tengah-tengah kota Jayapura memiliki Akreditas "A" yang beralamat di Jl. Raya Abepura Entrop, Entrop, Kec. Jayapura Selatan, Kota Jayapura Provinsi Papua. Memiliki ruang kelas sebanyak 22 kelas, 3 Laboratorium dan 1 Perpustakaan. Dalam sistem pembelajarannya menggunakan Kurikulum 2013. SMP Negeri 5 Jayapura memiliki total 335 siswa laki-laki, 274 siswa perempuan dan 41 guru [12].

SDS NUR HIDAYAH mengadakan pelatihan tatap muka. Proses pendistribusian materi kepada siswa biasanya diteruskan ke guru. Dimana guru meberikan materi yang dipindahkan ke papan tulis. Akan tetapi terkadang proses pendistribusian materi tidak dicatat oleh siswa, siswa tidak bisa mengulang pelajaran di rumah. Apalagi di jaman sekarang ini, guru tidak bisa berinteraksi langsung dengan siswa untuk memberikan materi, mereka hanya bisa bekerja sama menggunakan aplikasi Whatsapp, dimana pembelajaran menggunakan WhatsApp kurang efektif, misalnya guru lupa menigatakan tugas siswa karena tidak terstruktur [13]. SMP N 4 Kubung adalah sekolah negri yang ada di Kabupaten Solok, yang terletak di Jl. Raya Panyakalan Kec.Kubung Panyakalan Kabupaten Solok Sumatera Barat. SMP N 4 Kubung masih belum memiliki akses berbasis web seperti pendaftaran online, website sekolah dan sistem pembelajaran disekolah tersebut masih secara manual yang mana proses mengajarnya masih terikat oleh waktu pembelajaran yang ada dan haru bertatap muka secara langsung dengan pengajar di sekolah.[14]. SMK Negeri 3 Sumbawa masih menggunakan metode konvensional yang kegiatan ajar mengajar di dalam kelas secara tatap muka pada waktu dan tempat yang bersamaan. Dimana dalam proses belajar, siswa dan siswi tidak bisa mengakses materi pelajaran secara digital karena belum adanya media yang bisa menyimpan dan berbagi materi atau informasi secara digital, baik tugas, materi, ujian dan lainnya. Seperti yang ada, waktu belajar siswa disekolah 8 jam perhari dalam seminggu, selain itu beberapa siswa memiliki kegiatan organisasi di dalam ataupun diluar sekolah [15].

Dari beberapa penelitian diatas, maka dapat disimpulkan e-learning dapat digunakan untuk mempermudah Guru dalam memberikan referensi/materi, mengelola berkas tugas dan mengetahui tingkat pemahaman siswanya mengenai materi yang telah diberikan. Permasalahan yang terjadi di SMP Negeri 5 Jayapura adalah selama proses ini pembelajaran antara guru dan siswa yang sangat terbatas. Proses pembelajaran berlangsung dari hari Senin hingga dengan Jumat mulai pukul 07.30 sampai dengan pukul 13.30. Tiap harinya terdapat 3 sampai 4 mata pelajaran yang diajarkan dan untuk satu mata pelajaran hanya berkisar 1 sampai 2 jam. Akibat hal ini interaksi guru dan siswa menjadi kurang interaktif, para siswa tidak memiliki banyak waktu dalam mengerjakan soal dan mendalami materi yang diberikan. Sehingga dapat terjadi kendala, seperti siswa kurang paham tentang materi pelajaran tertentu, akan sulitan jika ingin mengulangi materi dan bertanya kepada guru yang ada secara langsung. Siswa juga tidak akan mendapatkan materi pelajaran dan tugas ketika guru berhalangan hadir, ini menyebabkan penyampaian materi pelajaran menjadi terhambat. Siswa hanya akan mendapatkan materi pembelajaran dari guru ataupun referensi buku yang ada di perpustakaan sekolah, hingga keterbatasan tempat dan waktu untuk mengaksesnya. 
JSAI : Journal Scientific and Applied Informatics

Vol. 4, No. 2, Juni 2021, hal. 154 164

E-ISSN: 2614-3054; P-ISSN: 2614-3062, accredited by Kemenristekdikti, Sinta 5

DOI: 10.36085

\section{METODE PENELITIAN}

Dalam penelitian ini dilakukan dengan menggunakan metode kualitatif deskriptif. Penelitian ini mengambil objek mengeni pembelajaran siswa yang diterapkan di SMP Negeri 5 Jayapura.

\section{Observasi}

Dalam hal ini, observasi yang dilakukan yaitu melihat langsung proses pembelajaran di SMP Negeri 5 Jayapura, serta data atau dokumen lainya yang dibutuhkan dalam penelitian ini.

\section{Wawancara}

Kegiatan wawancara dilakukan dengan Kepala Sekolah dan beberapa orang Guru SMP Negeri 5 Jayapura.

\section{Studi Literatur} lainnya.

Pengumpulan data dokumen yang berupa data siswa, data guru, data ujian, laporan hasil ujian dan

Tahapan-tahapan yang dilakukan dalam penelitian ini adalah dapat dilihat pada gambar 1 dibawah ini.

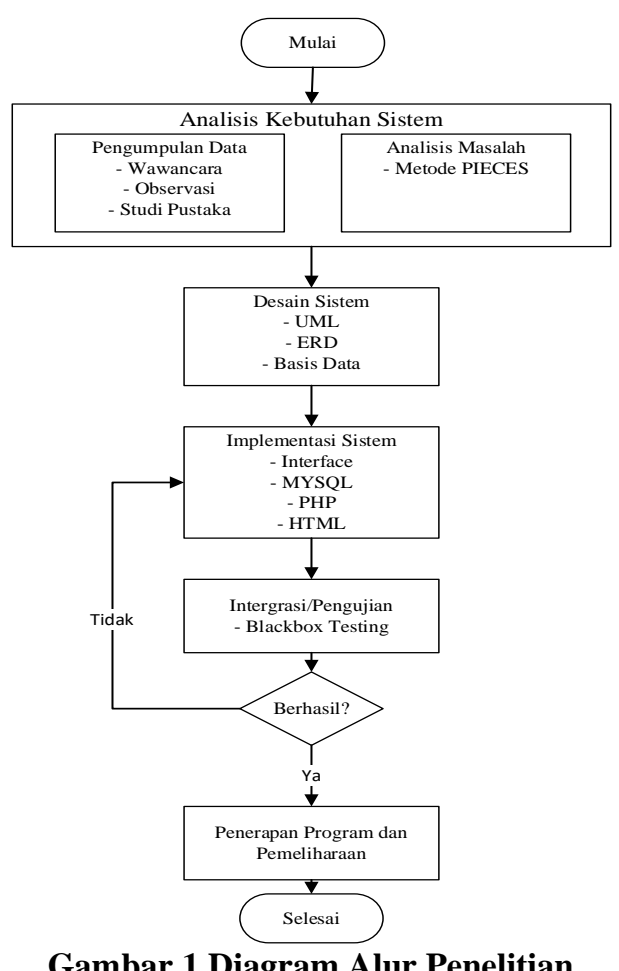

\section{A. Metode Pengembangan}

\section{Gambar 1 Diagram Alur Penelitian}

Metode pengembangan yang digunakan adalah metode waterfall. Metode ini digunakan karena merupakan suatu metode yang praktis dan cukup menghemat biaya karena semua parameter-parameter yang dibutuhkan serta hasil yang diinginkan dapat langsung dimodelkan dan disimulasikan dengan menggunakan suatu program komputer dalam bentuk perangkat lunak. Selain itu, struktur tahap pengembangannya jelas, dokumentasi yang dihasilkan di setiap pengembangan dan sebuah tahap dijalankan setelah tahap sebelumnya selesai dijalankan. 


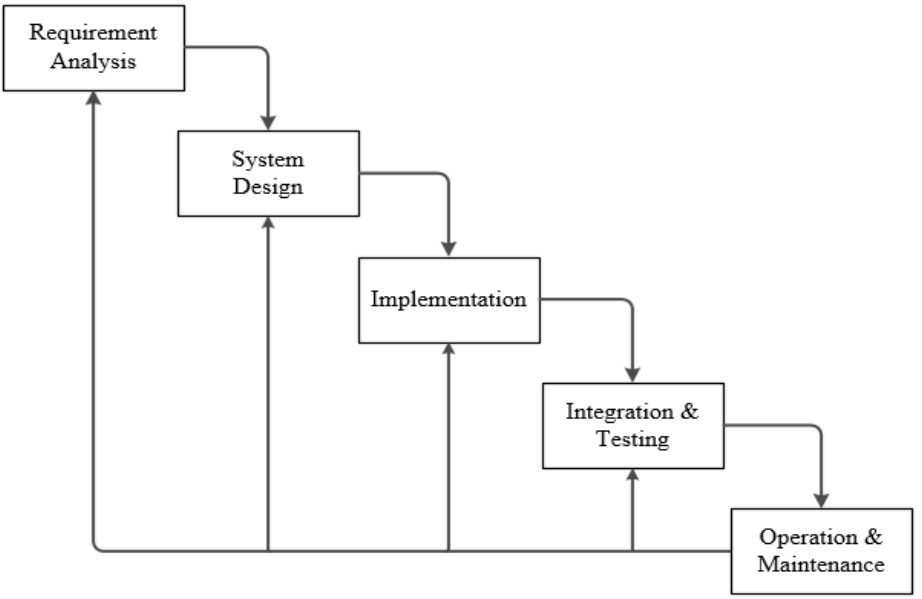

Gambar 2 Metode Waterfall

\section{B. Metode Analisis Sistem}

Metode analisis yang digunakan dalam penelitian ini yaitu metode Performance, Information, Economic, Control, Efficiency, Service (PIECES). Metode ini dipilih karena dapat mengidentifikasi masalah pada suatu sistem berdasarkan enam komponen, sehingga masalah tersebut dapat dipahami dengan baik.

Analisis PIECES ini sangat penting untuk dilakukan sebelum mengembangkan sebuah sistem informasi karena dalam analisis ini biasanya akan ditemukan beberapa masalah utama maupun masalah yang bersifat gejala dari masalah utama. Metode ini menggunakan enam variabel evaluasi yaitu:

1. Performance

Kinerja merupakan variable pertama dalam metode analisis PIECES. Dimana memiliki peran penting untuk menilai apakah proses atau prosedur yang ada masih mungkin ditingkatkan kinerjanya, dan melihat sejauh mana dan seberapa handalkah suatu sistem informasi dalam berproses untuk menghasilkan tujuan yang diinginkan. Dalam hal ini kinerja diukur dari:

a. Throughput, yaitu jumlah pekerjaan, output atau deliverables yang dapat dilakukan atau dihasilkan pada saat tertentu.

b. Response time, yaitu waktu yang dibutuhkan untuk menyelesaikan serangkaian kegiatan untuk menghasilkan output/deliverables tertentu.

\section{Information}

Menilai apakah prosedur yang ada saat ini masih dapat diperbaiki sehingga kualitas informasi yang dihasilkan menjadi semakin baik. Informasi yang disajikan haruslah benar-benar mempunyai nilai yang berguna. Hal ini dapat di ukur dengan:

a. Keluaran (output): Suatu sistem dalam memproduksi keluaran.

b. Masukan (input): Dalam memasukkan suatu data sehingga kemudian diolah untuk menjadi informasi yang berguna.

\section{Economic}

Menilai apakah prosedur yang ada saat ini masih dapat ditingkatkan manfaatnya (nilai gunanya) atau diturunkan biaya penyelenggaraannya.

\section{Control}

Menilai apakah prosedur yang ada saat ini masih dapat ditingkatkan sehingga kualitas pengendalian menjadi semakin baik, dan kemampuannya untuk mendeteksi kesalahan/ kecurangan menjadi semakin baik pula.

\section{Efficiency}

Menilai apakah prosedur yang ada saat ini masih dapat diperbaiki, sehingga tercapai peningkatan efisiensi operasi, dan harus lebih unggul dari pada sistem manual.

\section{Service}

Menilai apakah prosedur yang ada saat ini masih dapat diperbaiki kemampuannya untuk mencapai peningkatan kualitas layanan. Buatlah kualitas layanan yang sangat user friendly untuk pengguna (end-user) sehingga pengguna mendapatkan kualitas layanan yang baik. 


\section{HASIL DAN PEMBAHASAN}

Pada tahap ini dilakukan implementasi tampilan sistem untuk menampilkan sistem yang dibangun. Implementasi tampilan sistem dapat dilihat pada gambar dibawah ini:

\section{A. Rencana Kebutuhan}

Pada tahap ini dilakukan analisa kebutuhan sistem informasi e-learning pada SMP Negeri 5 Jayapura untuk merencanakan kebutuhan, mengidentifikasi masalah dan memberikan suatu solusi terhadap permasalahan yang ada selama ini.

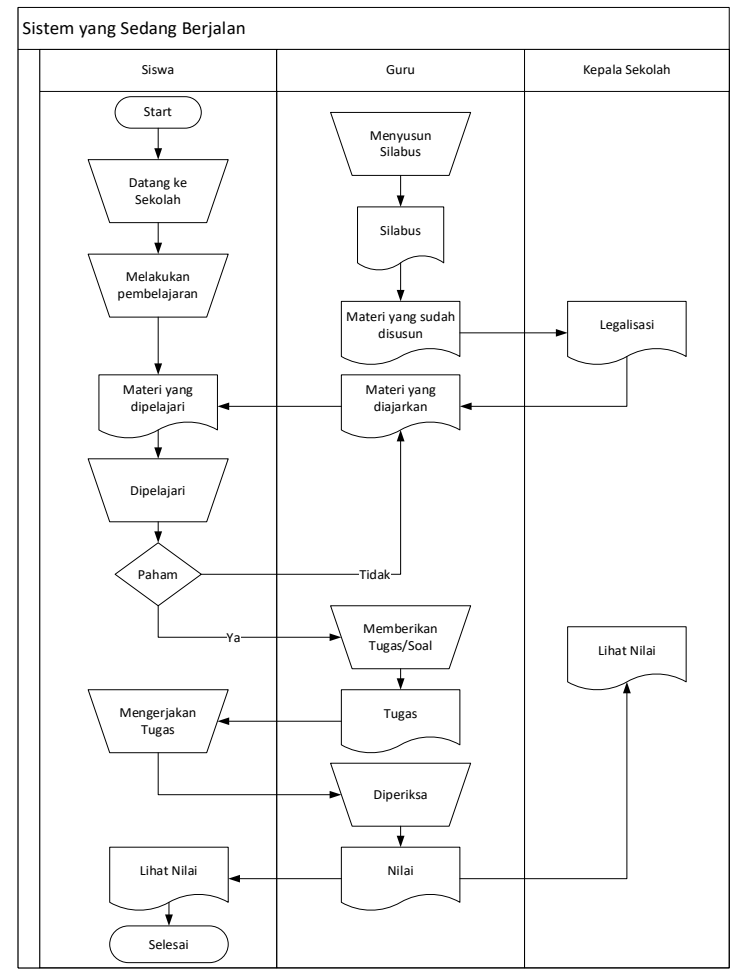

Gambar 3 Alur Sistem yang Sedang Berjalan

Sistem yang sedang berjalan saat ini di SMP Negeri 5 Jayapura. Siswa datang kesekolah untuk melaksankan pembelajaran. Masing-masing guru menyiapkan silabus, silabus adalah rencana pembelajaran pada suatu atau kelompok mata pelajaran/tema tertentu yang mencakup standar kompetensi, kompetensi dasar, materi pokok/pembelajaran, kegiatan pembelajaran, indikator pencapaian kompetensi untuk penilaian, penilaian, alokasi waktu, dan sumber belajar. Setelah itu disusun materi yang kemudian akan dilegalisasi oleh Kepala Sekolah. Setelah dilakukan legalisasi maka materi akan diberikan kepada siswa untuk dipelajari. Apabila siswa mengerti atau paham dengan materi yang diajarkan, maka siswa diberikan tugas, jika masih kurang mengerti dapat bertanya kepada guru ataupun mempelajari ulang materi tersebut. Tugas yang telah dikerjakan oleh siswa kemudian diperika oleh guru. Guru menilai tugas masing-masing siswa dan memberikan nilai. Nilai siswa kemudian diberikan kepada Kepala Sekolah dan siswa agar dapat melihat nilai.

\section{B. Analisis Sistem}

Tabel 1 Analisis PIECES

\begin{tabular}{|l|l|l|}
\hline \multicolumn{1}{|c|}{ Analisis } & \multicolumn{1}{|c|}{ Sistem Lama } & \multicolumn{1}{c|}{ Sistem Baru } \\
\hline $\begin{array}{l}\text { Performance } \\
\text { (Kinerja) }\end{array}$ & $\begin{array}{l}\text { Sistem pembelajaran dilakukan } \\
\text { masih bersifat manual, yaitu siswa } \\
\text { datang ke sekolah untuk } \\
\text { mendapatkan materi dan tugas. }\end{array}$ & $\begin{array}{l}\text { Sistem berbasis komputer, } \\
\text { yaitu menggunakan perangkat } \\
\text { lunak untuk proses } \\
\text { pembelajaran, sehingga siswa } \\
\text { dapat menerima materi dan } \\
\text { juga tugas kapan saja dan } \\
\text { dimana saja. }\end{array}$ \\
\hline
\end{tabular}


JSAI : Journal Scientific and Applied Informatics

Vol. 4, No. 2, Juni 2021, hal. 154 164

E-ISSN: 2614-3054; P-ISSN: 2614-3062, accredited by Kemenristekdikti, Sinta 5

DOI: 10.36085

\begin{tabular}{|c|c|c|}
\hline Analisis & Sistem Lama & Sistem Baru \\
\hline $\begin{array}{l}\text { Information } \\
\text { (Informasi) }\end{array}$ & $\begin{array}{l}\text { Sistem lama, informasi mengenai } \\
\text { nilai siswa diterima sangat lama } \\
\text { karena harus diperiksa satu-satu } \\
\text { oleg guru. }\end{array}$ & $\begin{array}{l}\text { Informasi mengenai hasil nilai } \\
\text { diterima dengan cepat karena } \\
\text { dilakukan oleh sistem. }\end{array}$ \\
\hline $\begin{array}{l}\text { Economy } \\
\text { (Ekonomi) }\end{array}$ & $\begin{array}{l}\text { Manfaat dari penggunaan sistem } \\
\text { lama kurang luas, karena tugas } \\
\text { siswa harus diperiksa satu per satu } \\
\text { oleh guru. }\end{array}$ & $\begin{array}{l}\text { Penggunaanya luas, karena } \\
\text { dapat melakukan penilaian } \\
\text { tugas siswa secara cepat dan } \\
\text { tepat. }\end{array}$ \\
\hline $\begin{array}{l}\text { Control } \\
\text { (Kontrol) }\end{array}$ & $\begin{array}{l}\text { Sistem yang lama, tugas masih } \\
\text { dikerjakan dengan kertas atau } \\
\text { lembar kerja siswa, sehingga } \\
\text { kertas dapat hilang atau tercecer. }\end{array}$ & $\begin{array}{l}\text { Sistem berbasis komputer } \\
\text { sehingga tugas-tugas siswa } \\
\text { dapat disimpan dengan aman. }\end{array}$ \\
\hline $\begin{array}{l}\text { Efficiency } \\
\text { (Efisiensi) }\end{array}$ & $\begin{array}{l}\text { Prosedur untuk melakukan } \\
\text { penilaian tugas siswa memakan } \\
\text { waktu yang lama. }\end{array}$ & $\begin{array}{l}\text { Prosedur untuk melakukan } \\
\text { penilaian tugas siswa dapat } \\
\text { dilakukan dengan cepat. }\end{array}$ \\
\hline Services & $\begin{array}{l}\text { Proses pencarian dan } \\
\text { pengumpulan nilai-nilai siswa } \\
\text { membutuhkan waktu yang cukup } \\
\text { lama dikarenakan harus mencari } \\
\text { nilai di arsip. }\end{array}$ & $\begin{array}{l}\text { Memudahkan dalam proses } \\
\text { pencarian dikarenakan semua } \\
\text { data ditampung di } \\
\text { penyimpanan sistem. }\end{array}$ \\
\hline
\end{tabular}

\section{Proses Desain Sistem}

1) Use Case Diagram Admin dan Pengajar

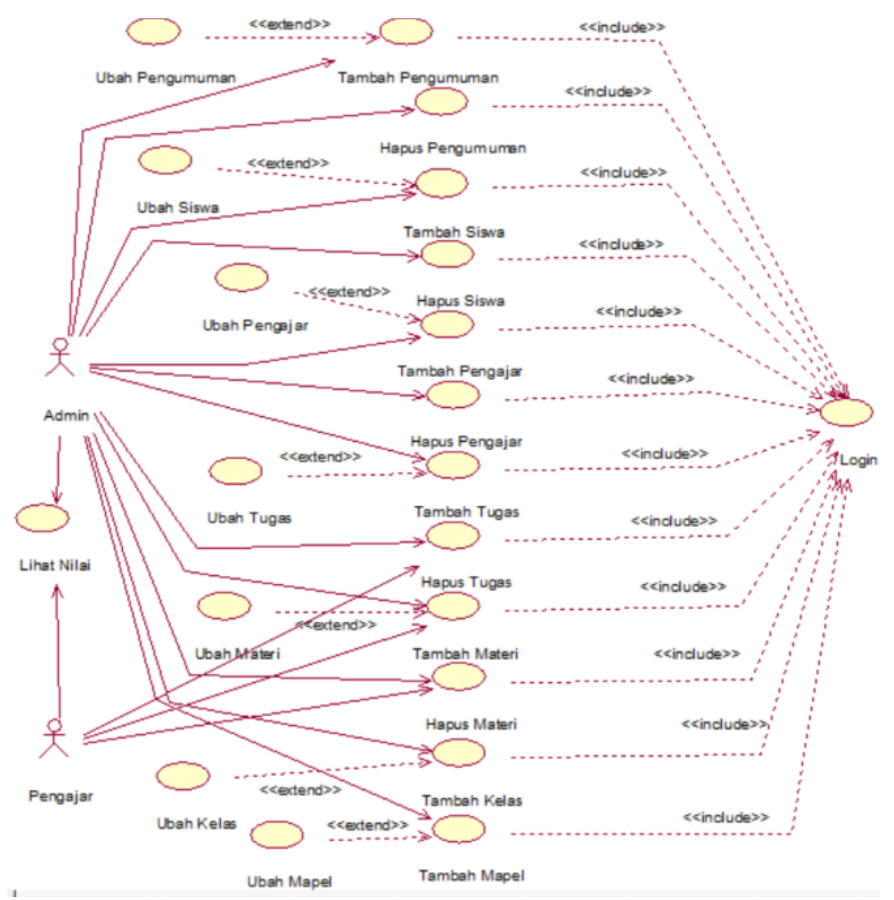

Gambar 4 Use Case Diagram

2) Perancangan AntarMuka

Tampilan halaman login merupakan halaman yang tampil pertama kali saat pengguna menggunakan aplikasi e-learning. Pengguna memasukkan username dan password, setelah itu menekan 
JSAI : Journal Scientific and Applied Informatics

Vol. 4, No. 2, Juni 2021, hal. 154 164

E-ISSN: 2614-3054; P-ISSN: 2614-3062, accredited by Kemenristekdikti, Sinta 5

DOI: 10.36085

tombol login dan direspon oleh sistem. Adapun tampilan halaman login ditunjukkan pada gambar dibawah ini.

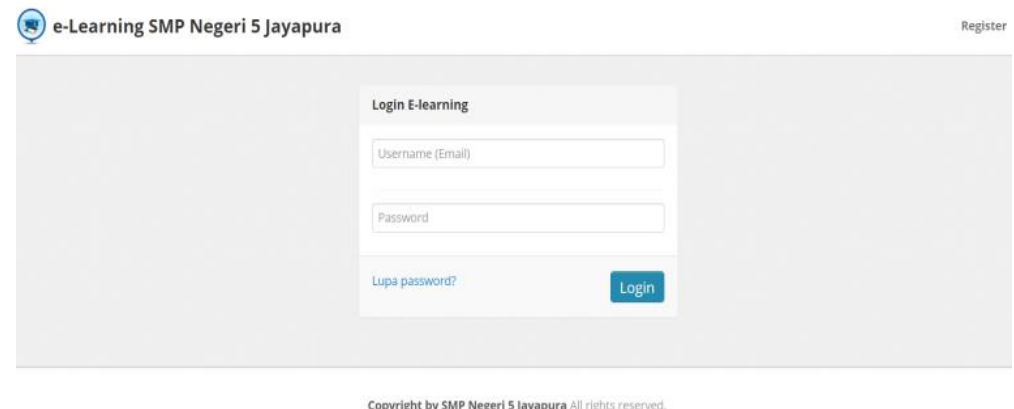

Gambar 5 Tampilan Halaman Login

Tampilan halaman utama sistem merupakan halaman yang tampil saat pengguna telah melakukan login. Terdapat berbagai menu diantaranya menu siswa, menu pengajar, menu tugas, menu materi dan lainnya. Adapun tampilan halaman utama sistem ditunjukkan pada gambar dibawah ini.

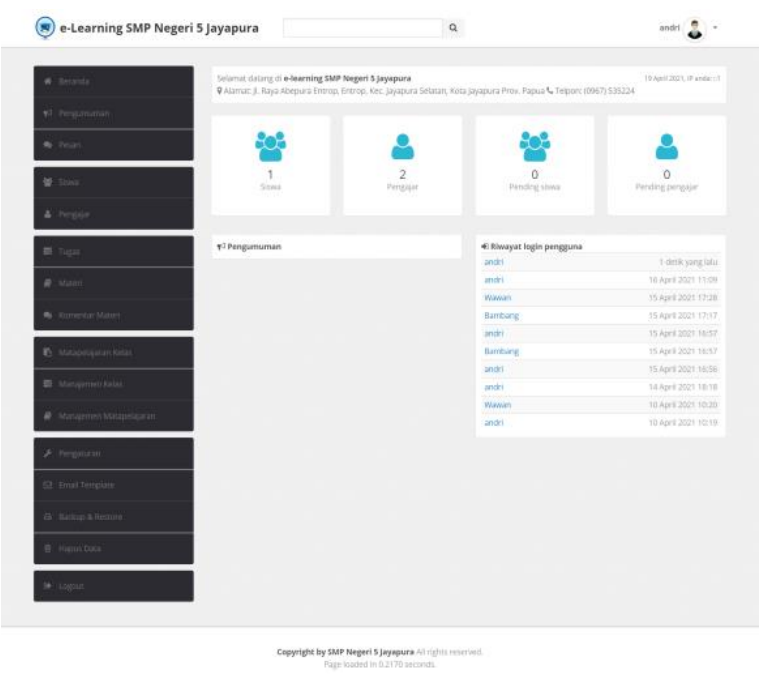

\section{Gambar 6 Tampilan Halaman Utama Sistem}

Tampilan halaman register merupakan halaman yang tampil saat pengguna ingin mendaftarkan diri sebagai siswa atau pelajar. Pengguna diwajibkan mengisi data-data seperti nama, jenis kelamin, agama dan lainnya yang diperlukan sistem. Adapun tampilan halaman register ditunjukkan pada gambar dibawah ini. 
JSAI : Journal Scientific and Applied Informatics

Vol. 4, No. 2, Juni 2021, hal. 154 164

E-ISSN: 2614-3054; P-ISSN: 2614-3062, accredited by Kemenristekdikti, Sinta 5

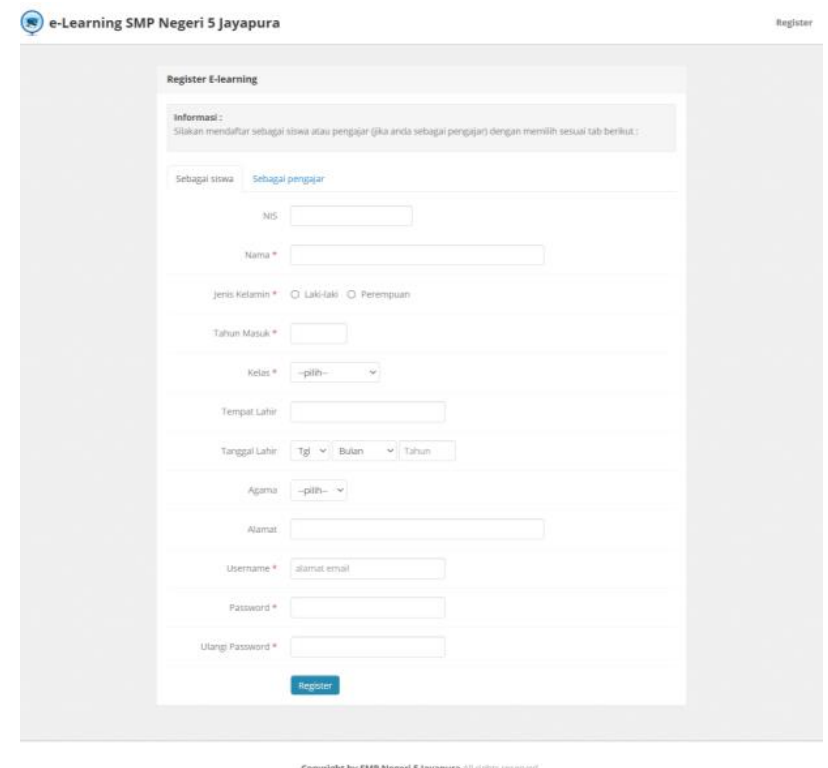

Gambar 7 Tampilan Halaman Register

Tampilan halaman siswa merupakan halaman yang tampil saat pengguna telah melakukan login. Admin dapat melakukan penambahan, perubahan dan penghapusan data siswa. Adapun tampilan halaman siswa ditunjukkan pada gambar dibawah ini.

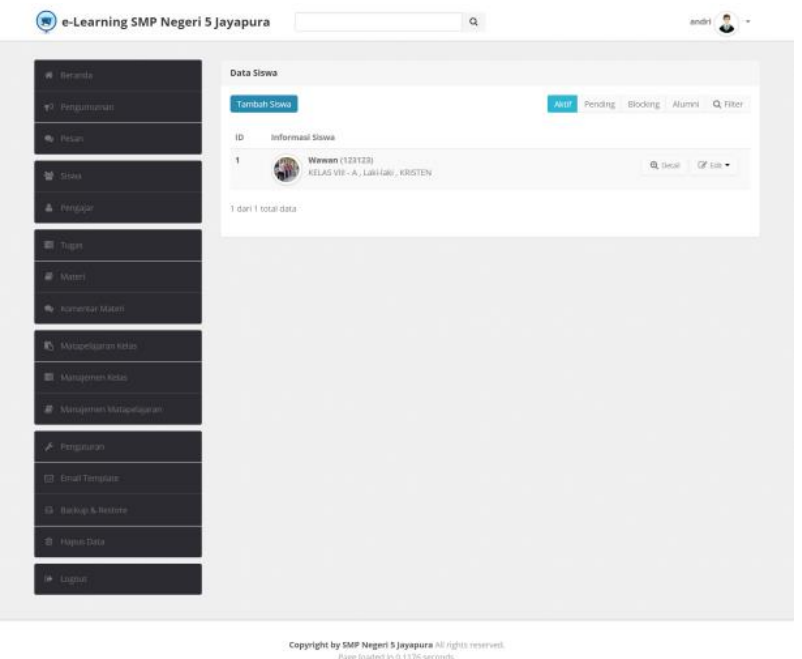

\section{Gambar 8 Tampilan Halaman Siswa}

Tampilan halaman pengajar merupakan halaman yang tampil saat pengguna telah melakukan login. Admin dapat melakukan penambahan, perubahan dan penghapusan data pengajar. Adapun tampilan halaman pengajar ditunjukkan pada gambar dibawah ini.

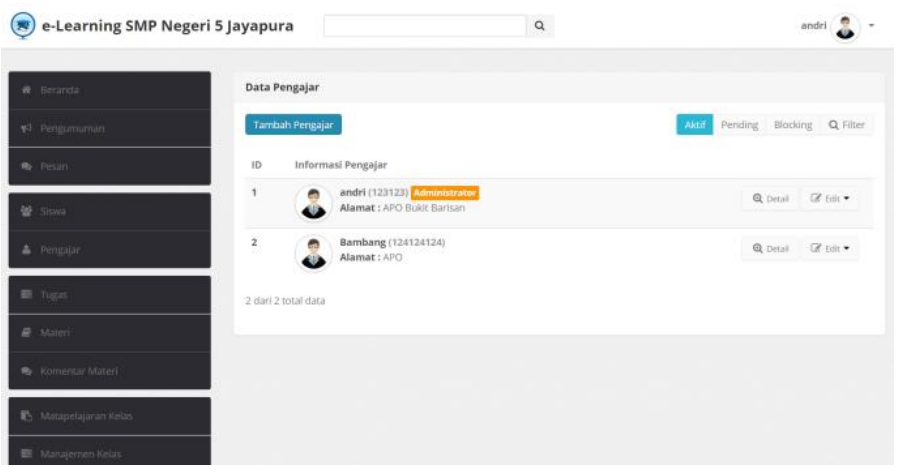

Gambar 9 Tampilan Halaman Pengajar 
Tampilan halalam tugas merupakan halaman yang tampil saat pengguna telah melakukan login. Admin dan guru dapat melihat tugas, menambah tugas pilihan ganda, tugas essay dan tugas yang bisa di upload, mengubah tugas dan menghapus tugas. Adapun tampilan halaman tugas ditunjukkan pada gambar dibawah ini.

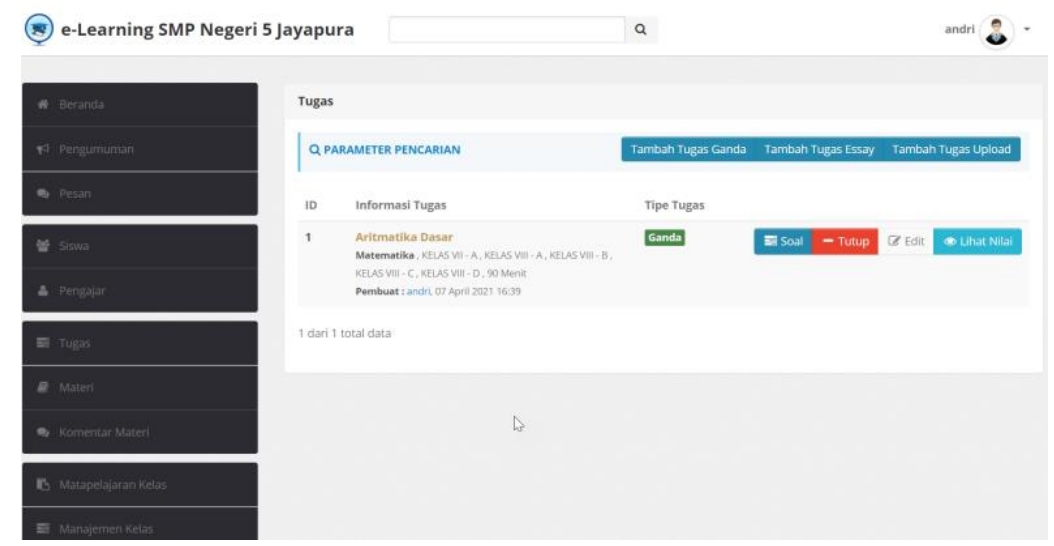

\section{Gambar 10 Tampilan Halaman Tugas}

Tampilan halaman materi merupakan halaman yang tampil saat pengguna telah melakukan login. Admin dan pengajar dapat menambahkan, mengubah dan menghapus data materi. Adapun tampilan halaman materi ditunjukkan pada gambar dibawah ini.

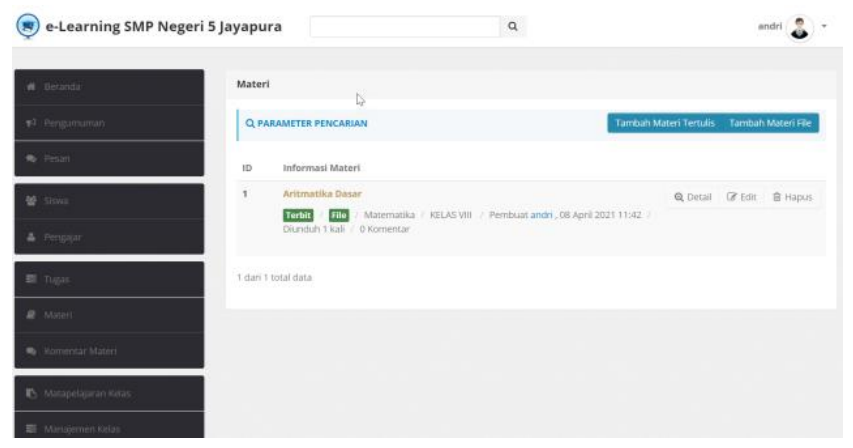

\section{Gambar 11 Tampilan Halaman Materi}

Tampilan halaman tambah tugas merupakan halaman yang tampil saat pengguna telah melakukan login. Admin dan guru dapat melakukan tambah tugas seperti judul, mata pelajaran, pilih kelas, info dan durasi pengerjaan tugas. Adapun tampilan halaman tambah tugas ditunjukkan pada gambar dibawah ini.

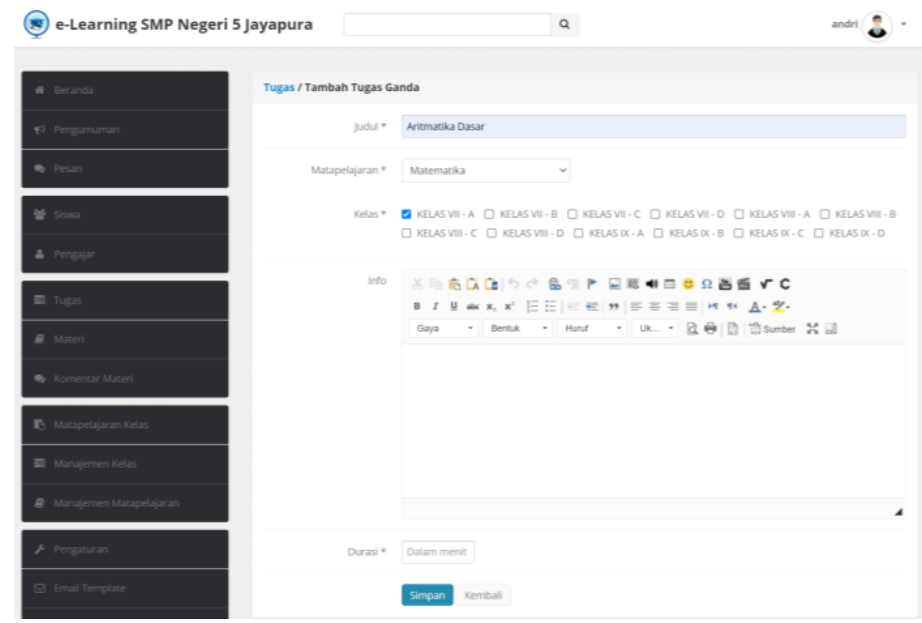

Gambar 12 Tampilan Halaman Tambah Tugas

Tampilan halaman tambah materi merupakan halaman yang tampil saat pengguna telah melakukan login. Admin dan guru dapat menambahkan data seperti, judul, mata pelajaran, pilih kelas dan konten. Adapun tampilan halaman tambah materi ditunjukkan pada gambar dibawah ini. 


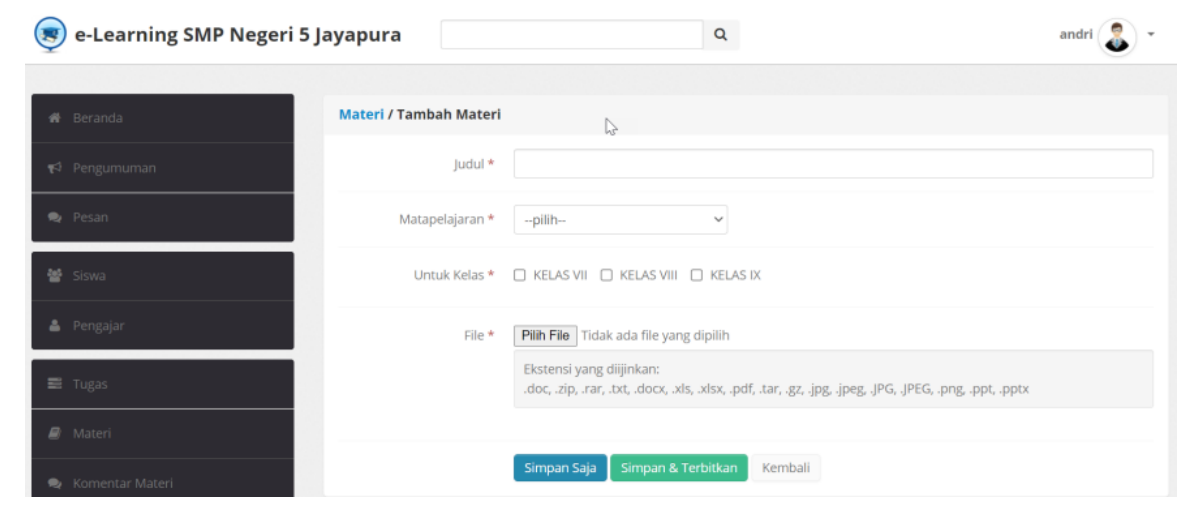

\section{Gambar 13 Tampilan Halaman Tambah Materi}

Tampilan halaman kerjakan tugas merupakan halaman yang tampil saat pengguna telah melakukan login. Siswa mengerjakan tugas yang diberikan oleh guru berdasarkan waktu yang telah ditentukan. Apabila waktu telah habis maka halaman akan ditutup secara otomatis. Adapun tampilan halaman kerjakan tugas ditunjukkan pada gambar dibawah ini.

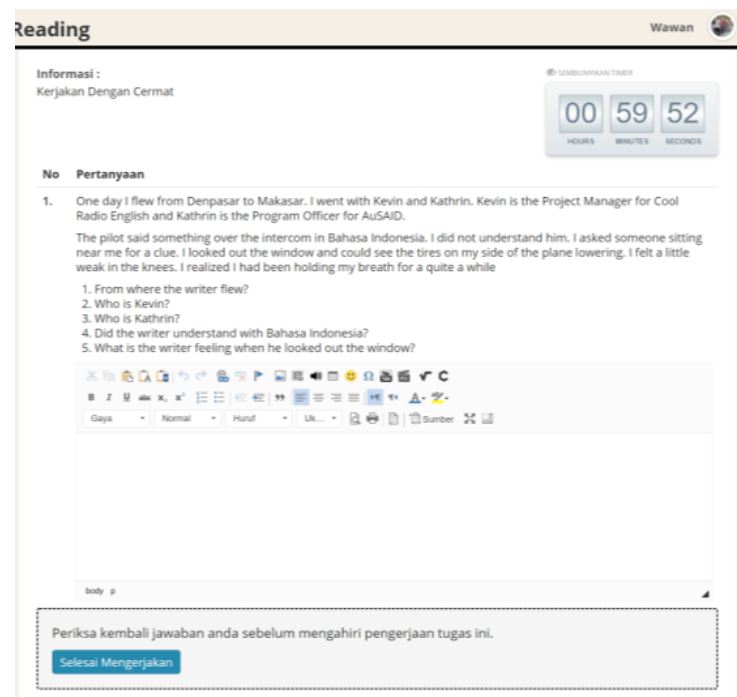

\section{Gambar 14 Tampilan Halaman Kerjakan Tugas}

Tampilan halaman lihat materi merupakan halaman yang tampil saat pengguna telah melakukan login. Siswa dapat melihat materi yang diberikan oleh guru. Siswa juga dapat mengunduh file materi yang diberikan oleh guru. Adapun tampilan halaman lihat materi ditunjukkan pada gambar dibawah ini.

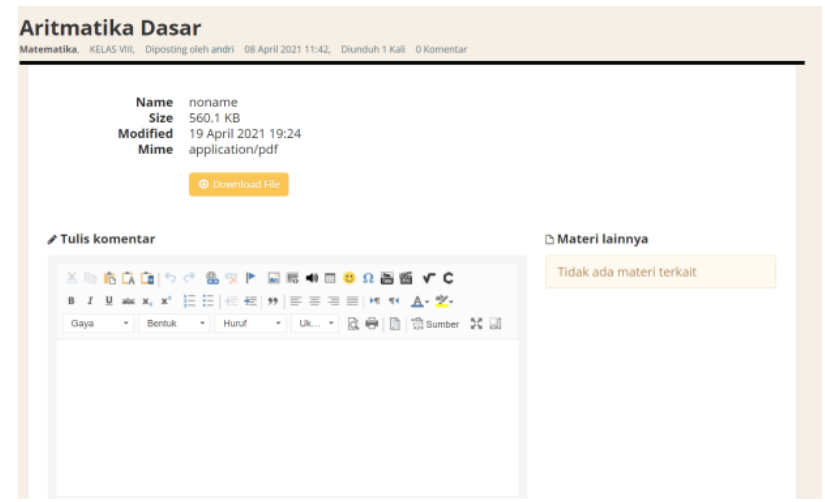

Gambar 15 Tampilan Halaman Lihat Materi

\section{Penutup}

Berdasarkan penelitian yang telah dilakukan oleh penulis, maka dapat ditarik suatu kesimpulan yaitu sistem yang dibangun dapat dapat digunakan sebagai media pembelajaran secara online tanpa terbatasi ruang dan waktu. Siswa mendapatkan materi pelajaran, tugas, dan dapat mengerjakan tugas yang ditambahkan oleh 
JSAI : Journal Scientific and Applied Informatics

Vol. 4, No. 2, Juni 2021, hal. 154 164

E-ISSN: 2614-3054; P-ISSN: 2614-3062, accredited by Kemenristekdikti, Sinta 5

DOI: 10.36085

guru dengan sistem. Guru juga dapat melihat hasil nilai tugas yang telah dikerjakan secara langsung sehinnga guru tidak perlu lagi menilai masing-masing siswanya secara manual.

\section{REFERENSI}

[1] E. Priyanti, R. B. Ansyah, F. Ramadhani, and H. Yaman, "Rancang Bangun Sistem Informasi E-Learning Pada Smk Pgri 37 Jakarta,” Swabumi, vol. 8, no. 1, pp. 76-79, 2020, doi: 10.31294/swabumi.v8i1.7456.

[2] I. W. K. Suwastika, "Pengaruh E-Learning Sebagai Salah Satu Media Pembelajaran Berbasis Teknologi Informasi Terhadap Motivasi Belajar Mahasiswa," J. Sist. dan Inform., vol. 3, no. 1, pp. 1-5, 2018.

[3] Satrianah and H. D. Yunita, "DEVELOPMENT OF E-LEARNING APPLICATIONS AS A MEANS OF ONLINE LEARNING IN SMP AL AZHAR 1 BANDAR LAMPUNG," $J$. Technol. Accept. Model, vol. 11, no. 1, pp. 10-19, 2020.

[4] D. Opoku, F. Pobee, and O. R. Okyireh, "Determinants of E-Learning System Adoption among Ghanaian University Lecturers : An Application of Information Sy ... Related papers," Am. J. Soc. Scienecs Humanit., vol. 5, no. 1, pp. 151-168, 2020, doi: 10.20448/801.51.151.168.

[5] A. Jameel, A. Nawaiseh, Y. Helmy, and E. Khalil, "A New Software Quality Model For Academic Information Systems " Case Study E-Learning System "," Int. J. Sci. Technol. Res., vol. 9, no. 01, 2020.

[6] J. Asmara, "Rancang Bangun Aplikasi E-learning Pada SMP N 2 Busalangga," JSAI (Journal Sci. Appl. Informatics), vol. 4, no. 1, pp. 85-94, 2021, doi:

10.36085/jsai.v4i1.1331.

[7] M. H. Riandi, H. Respati, and S. Hidayatullah, "Conceptual Model of User Satisfaction as Mediator of E-Learning Services and System Quality on Students' Individual Performance,” Int. J. Res. Engginering, Sci. Manag., vol. 4, no. 1, pp. 60-65, 2021.

[8] A. Priamnistiko, Y. Handrianto, and S. H. Sukmana, "Rancang Bangun Sistem Informasi ELearning Menggunakan Model Waterfall," J. Inov. Inform., vol. 6, no. 1, pp. 50-57, 2021.

[9] K. Aisah and H. Yanto, "PERANCANGAN SISTEM INFORMASI APLIKASI ELEARNING BERBASIS WEB DI SMA N 9 PADANG," vol. 8, no. 1, pp. 66-72, 2021.

[10] D. F. Purba and H. Tambunan, "PENGEMBANGAN MEDIA PEMBELAJARAN ELEARNING MENGGUNAKAN MOODLE BERBASIS E-MODUL PADA PEMBELAJARAN INTALASI," J. Electr. Vocat. Teach. Educ., vol. 1, no. 1, pp. 35-39, 2021.

[11] F. Nadziroh, “Analisa Efektifitas Sistem Pembelajaran,” J. Ilmu Komput. dan Desain Komun. Vis., vol. 2, no. 1, pp. 1-14, 2017.

[12] T. Dapodikbud, "SMP NEGERI 5 JAYAPURA," Dapodikbud, Tim, 2017. http://sekolah.data.kemdikbud.go.id/index.php/chome/profil/B0685041-31F5-E011-B8A8FD1ED44E423B (accessed Mar. 20, 2021).

[13] S. Alfiasyahri and P. Simanjuntak, "RANCANG BANGUN E-LEARNING BERBASIS WEBSITE DI SDS ISLAM NURHIDAYAH BATAM," J. Comasie, vol. 3, no. 3, pp. 2130, 2021.

[14] S. Yanti and M. Rafqi, "Sistem Informasi E-Learning Berbasis Web Pada SMP N 4 Kubung Kabupaten Solok," pp. 291-296, 2020.

[15] Herfandi, A. Diansyah, and E. Susanto Sasmita, "RANCANG BANGUN E-LEARNING BERBASIS WEB PADA SMK NEGERI 3 SUMBAWA,” vol. 2, no. 4, pp. 223-233, 2020. 